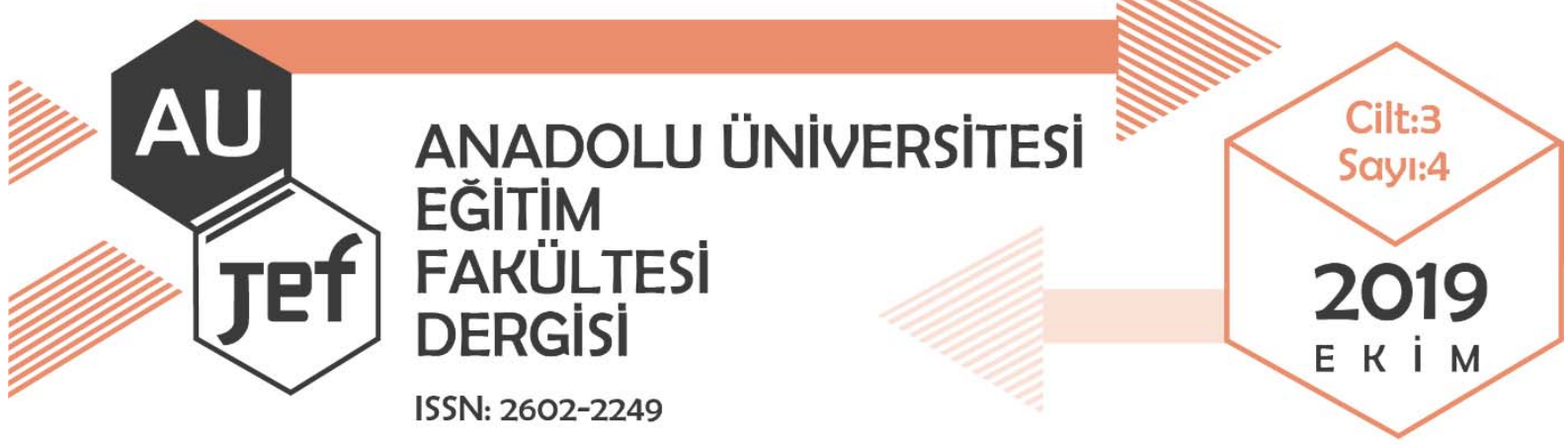

Fransızca Yabancı Dil Öğrencilerinin Olumsuz Değerlendirilme Korkusu ve Özyeterlilik İnançları

\title{
The Fear of Negative Evaluation and Self-Efficacy Beliefs of French Foreign Language Students
}

Meltem ERCANLAR ${ }^{1}$

Başvuru Tarihi: 08.07.2018

Kabul Tarihi: 03.09.2019

Atıf İçin: Ercanlar, M. (2019). Fransızca yabancı dil öğrencilerinin olumsuz değerlendirilme korkusu ve özyeterlilik inançlar1. Anadolu Üniversitesi Ĕ̈itim Fakültesi Dergisi (AUJEF), 3(4), 239-252.

ÖZ: Bu araştırmada Fransızca yabancı dil öğrencilerinin olumsuz değerlendirilme korkusu ve genel özyeterlilik algıları incelenmiş, bu iki değişken arasındaki ilişki ortaya konmaya çalışılmıştır. Araştırmanın örneklemini, Eskişehir Anadolu Üniversitesi’nde Fransızca Öğretmenliği Programında 2017-2018 eğitim öğretim yılı bahar döneminde öğrenim görmekte olan 122 öğrenci oluşturmaktadır. Araştırmanın verileri "Olumsuz Değerlendirilme Korkusu Kısa Formu” ve “Genel Özyeterlilik Ölçeği” kullanılarak toplanmıştır. Verilerin analizi sırasında tek örneklem t-testi, Pearson korelasyon analizi ve tek yönlü ANOVA yapılmıştır. Araştırmadan elde edilen sonuçlara göre Fransızca yabancı dil öğrencilerinin genel özyeterlilik düzeyi yüksek, olumsuz değerlendirilme korkusu düzeyi ise düşük çıkmıştır. Ayrıca bu iki değişken arasında negatif ve orta düzeyde, anlamlı bir ilişki olduğu saptanmıştır. Öğrencilerin öğrenim gördüğü sınıfın ise olumsuz değerlendirilme korkusu ve genel özyeterlilik değişkenleri açısından fark oluşturmadığı görülmüştür.

Anahtar sözcükler: Kaygı, olumsuz değerlendirilme korkusu, özyeterlilik, yabancı dil öğretimi

ABSTRACT: This study was carried out to investigate the level of fear of negative evaluation and self-efficacy beliefs of French language teaching students and the relationship between these two variables. The sample consisted of 122 students majoring French Language Teaching during the Spring Semester of 2017-2018 Academic Year at Eskisehir Anadolu University. The data were collected by "The Brief Fear of Negative Evaluation Scale" and "The General Self-Efficacy Scale". The data were analyzed using one sample t-test, Pearson correlation analysis and one-way ANOVA. The results revealed that the level of general self-efficacy of French language teaching students was high and the level of their fear of negative evaluation was low. Besides, it was found that there is a positive moderate and statistically significant relationship between the fear of negative evaluation and the general self-efficacy beliefs. The grade in which the sample studied did not differ in terms of fear of negative evaluation and general self-efficacy variables.

Keywords: Anxiety, fear of negative evaluation, self-efficacy, foreign language teaching

\footnotetext{
${ }^{1}$ Araştırma Görevlisi, Anadolu Üniversitesi, Eğitim Fakültesi, meltemercanlar@anadolu.edu.tr, ORCID: 00000002-3175-9162
} 


\section{GİRIŞ}

Yabancı dil öğretiminde amaç bireylere hedef dilde iletişim becerisi edindirme, genel ve bildirişimsel yeterlikleri kazandırmaktır. Bu yeterliklerin kazandırılma sürecinde çoğunlukla bilişsel özellikler öne çıkmakta, duyuşsal ve sosyokültürel olanlar arka planda kalmaktadır. Hâlbuki duygular, inançlar, tutum ve görüşler gibi duyuşsal özellikler dil öğrenme sürecini oldukça fazla etkilemektedir. Öğrenmenin duyuşsal boyutu bireysel farklılıkları göz önüne çıkarır ve onlara öncelik verir. Arnould'un (2006) da belirttiği gibi yabancı dil sınıflarında başarı "ş̧eyler"den çok "kişilere" bağlıdır. Burada kişilerden anlaşılması gereken; kaygı, çekingenlik, özsaygı, öz yeterlilik, öğrenme stilleri ve güdülenme gibi bireysel özelliklerdir. Diller için Avrupa Ortak Öneriler Çerçevesi'nde de (AOÖÇ, 2013) dil öğretiminde duyuşsal faktörlerin ve bireysel farklılıkların önemine değinilmiş, dil kullanıcılarının genel becerileri ve yeterlikleri arasında "kişiye ilişkin yeterlik" (savoir-être) olarak adlandırılan yeterlik de eklenmiş ve şu şekilde tanımlanmıştır:

"Dili kullananların/öğrenenlerin bildirişimsel etkinlikleri, sadece onların bilgi, anlayış ve becerilerinden etkilenmez; ayrica kişisel etmenlerden, onların tutumlarl, güdüleri, değerleri, inandıkları, bilişsel tarzları ve kişilik türleri gibi kişiliğini oluşturan etmenlerden de etkilenir" (AOÖÇ, 2013:106).

Bireysel faktörler; öğrenenlerin tutumları, güdüleri, değer ve inançları, kişilik özellikleri olarak sıralanabilir. Kişilkle ilgili etmenler arasında ise "girişkenlik/çekingenlik", "korku ya da mahcubiyet", "benlik algısı (veya eksikliği)”, “özgüven (veya eksikliği)”, “öz bilinç (veya eksikliği)”, "kendine değer verme duygusu (veya eksikliği)" gibi özellikler sıralanmaktadır (idem. 107). Bu kişilik özellikleri öğrenenin öğrendiği nesneyle arasındaki ilişkiyi oldukça etkilemektedir. Kişinin girişken, özgüvenli ve öz biliçli olması sözel iletişimi kolaylaştırırken; çekingen, kaygılı ve düşük öz güvenli olması iletişimi sekteye uğratabilmektedir. Yabancı dil öğrenenlerin kendi ana dillerinde iletişim kurarken de etkilerini gördükleri bu özellikler dil öğretiminde göz ardı edilmemesi gereken bir konudur. Bu alanda üzerinde en fazla çalışılan faktör öğrenmeye ket vuran, yabancı dil öğrenimini ve yabancı dilde iletişime geçmeyi zorlaştıran bir özellik olarak kaygı ve korku (anksiyete) olarak karşımıza çıkmıştır. Kaygı korku, hayal kırıklığı, gerilim ve güvensizlik gibi duygularla ilişkilidir. Normal düzeyde olması öğrenmeyi ve başarıyı olumlu etkileyebilirken, aşırısı öğrenmeyi engelleyen, başarıyı olumsuz etkileyen bir faktördür. Yabancı dil öğretiminde dilsel kaygının olumlu ve olumsuz etkilerini ortaya koyan pek çok çalışma (Chen \& Chang 2004; Çapan, 2015; Öner \& Gedikoğlu, 2007; Young, 1991; Yoğurtçu \& Yoğurtçu, 2013) mevcuttur.

Kayg1, "otonom sinir sisteminin uyarılmasıyla ilişkili öznel gerilim, endişe, sinirlilik ve endişe hissi" olarak tanımlanmaktadır (Spielberg, 1983, akt. Huang, 2012, s.2). Yabanc1 dil kaygısı ise "ikinci bir dili öğrenirken ya da kullanırken ortaya çıkan endişe ve olumsuz duygusal tepki” olarak tanımlanmaktadır (Young, 1999, ak. Hamamc1 \& Hamamc1, 2015, s.375). Young (1991, s. 427), dilsel kaygının altı nedeni olduğunu öne sürmüştür. Bunlar;

1. Kişisel ve kişilerarası kaygılar,

2. Öğrenenin dil öğrenimine ilişkin inançları,

3. Öğretenin dil öğretimine ilişkin inançları,

4. Öğreten- öğrenen arasındaki ilişki,

5. Sinıf uygulamaları,

6. Ölçme- değerlendirmedir.

Anadolu Üniversitesi Ĕ̆itim Fakültesi Dergisi (AUJEF), 3(4), 239-252 
Young'a (ibid.) göre, düşük özsaygı ve rekabet de dil kaygısının önemli nedenleri arasındadır. Yabancı dil kaygısı teorisini ilk ortaya atanlardan Hortwitz ve arkadaşları (Hortwitz vd. 1986, akt. Çapan, 2015) ise dilsel kaygının üç nedeni olduğunu söyler: iletişime girme korkusu, sınav korkusu ve olumsuz değerlendirilme korkusu. İletişime girme korkusu diğerleriyle iletişim kurmaya çekinme ve utanmayla ilgiliyken, sınav korkusu başarısız olma, kötü not alma gibi kaygılarla ilgilidir. Olumsuz değerlendirilme korkusu ise sadece sınıf ortamında değil sosyal ortamlarda da karşılaşılabilecek bir korkudur ve sosyal fobiyle ilgilidir. Sınıf ortamında öğretmen ya da akranların olumsuz yorumlarından ve değerlendirmelerinden çekinmeyi ifade etmektedir. Yabancı dil sınıflarında özellikle performans göstermeyi gerektiren durumlarda (sözlü sunum, konuşma, rol oynama, vb.) öğrenci devamlı olarak öğretmen ve diğer öğrenciler tarafından izlenmekte ve değerlendirilmektedir. Olumsuz değerlendirilme kaygısı yaşayan birey, sürekli olarak diğerlerinin onun hakkında olumsuz yorumlarda bulunacağını ya da onunla dalga geçileceğini düşünüyor olabilir. Sınav kaygısının biraz daha ötesine geçen olumsuz değerlendirilme korkusu "bireylerin kişilerarası ilişkilerinde ya da performans göstermesi gereken durumlarda başkaları tarafından küçük düşürücü, aşağılayıcı, değersizleştirici ve küçümseyici vb. biçimde değerlendirileceklerine yönelik yaşadıkları korku ve kaygı" olarak tanımlanmaktadır (Doğan, 2009, s.9). Olumsuz değerlendirilme korkusu yüksek olan bireyin dilsel kaygı yaşama olasılığı daha güçlüdür.

İnsan davranışı kişisel özellikler, kendine yönelik inanışlar ve dışsal çevresel faktörler gibi bir arada bulunan pek çok etmenden etkinlenmektedir. İnançlar dil öğrenenlerin öğrenme motivasyonunu da etkileyebilen önemli kişisel özelliklerdir. Kişinin kendine yönelik inançları arasında öğrenmeyi etkilediği çeşitli çalışmalar tarafından ortaya konmuş olan öz yeterlilik inancı, kişinin belirlenmiş bir görevi yerine getirme ya da bir etkinliği tamamlama yeteneği hakkındaki inanacı olarak tanımlanabilir (Mills, 2014). Bandura'ya (1997:19) göre kişinin öz yeterlilik inanc1 neredeyse yaptığı her şeyi, nasıl düşündüğünü, hissettiğini, davrandığını ve kendini nasıl güdülediğini etkiler. Alanyazında yapılan pek çok çalışma öz yeterlilik inancı ve akademik başarı arasında bir ilişki olduğunu ortaya koymuş, öz yeterlilik inançları yüksek düzeyde olan öğrencilerin akademik olarak daha başarılı olduklarını göstermiştir (Bandura, 1997; Mills, 2014; Rahimi ve Abedini, 2009). Ayrıca öz yeterlilik inanc1 ile yabancı dil kaygısı arasındaki bağlatıyı ortaya koyan çeşitli çalışmalar da mevcuttur (Çubukçu, 2008; Güngör ve Yayl1, 2012; Mills, Pajares ve Herron, 2008).

İkinci dil öğretiminde güdüleri ve öz yeterlilik inaçları yüksek, kaygı düzeyi düşük bir sinıf ortamının öğrenmeyi destekleyici rolü artık herkes tarafından kabul gören bir gerçekliktir. Ancak güncel yabancı dil öğretimi yaklaşımlarına (iletişimsel yaklaşım ve eylem odaklı yaklaşım) göre yürütülen derslerde dilsel kaygı düzeyinin daha yüksek olması daha olası düşünülmektedir zira bu yaklaşımlara göre yabanc1 dil öğrenmek daha fazla iletişime girmeyi ve eyleme geçmeyi gerektirmektedir. Dolayısıyla dil öğrenirken aktif olmak ve harekete geçmek öğrencilerin kayg1 düzeylerini artırabilen bir durumdur. Dilsel kaygı çok boyutlu ve karmaşık bir durumdur ve çok farklı şekillerde tanımlanmış, çeşitli özellikleri ortaya konmuş, olumsuz etkileri ve nasıl azaltılacağı üzerine pek çok araştırma (Aslım Yetiş, 2012; Öner \& Gedikoğlu, 2007; MacIntyre, 1995) yürütülmüştür. Bu nedenle, bu çalışmada amaç, dilsel kaygıyı enine boyuna tartışmak değil, onun kaynaklarından biri olarak kabul edilen olumsuz değerlendirilme korkusu ve onu dolaylı olarak etkilediği düşünülen genel özyeterlilik inancını sorgulamaktır.

Alanyazında yapılan çalışmalar incelendiğinde dilsel kaygının olumlu ve olumsuz etkileri, nedenleri, çeşitleri, diğer duyuşsal özellikler ile arasındaki ilişkiler, vb. pek çok çeşitli çalışmaya rastlamak mümkündür. Türkiye'de yapılan çalışmalarda dilsel kaygı düzeyi ölçülmüş ve buna yönelik 
pek çok öneri getirilmiştir. Fakat dilsel kayğının nedenleri ve ilişkili olduğu kişisel özellikleri inceleyen çalışmalar çok fazla değildir. Özellikle de olumsuz değerlendirilme korkusunun dilsel kaygının önemli nedenlerinden biri olduğu göz önüne alındığında bu konuda daha derinlemesine yapılan çalışmalara olan ihtiyaç ortaya çıkmaktadır. Koralp (2005), öğrencilerin farklı türde kayg1 düzeylerini ölçtüğü çalışmasında, sınav kaygısıyla olumsuz değerlendirilme kaygısı arasında pozitif bir ilişki olduğunu ortaya koymuştur. Aydın'ın (2008) İngilizce yabancı dil öğrencileriyle yaptığı betimsel çalışmaya göre ise dilsel kaygı ve olumsuz değerlendirilme korkusu arasında pozitif bir ilişki vardır. Aydın olumsuz değerlendirilme korkusunun yabancı dil kaygısının güçlü nedenlerinden biri olduğunu belirtmiştir. Ayrıca öğrencilerin olumsuz değerlendirilme korkusunun kaynaklarını şu şekilde sıralamıştır: başkaları tarafından olumsuz yargılanma, başkalarının üzerinde kötü izlenim bırakma, konuşurken dilsel hatalar yapma ve diğerleri tarafindan onaylanmama. Merç (2015) ise, İngilizce öğretmen adaylarının yaşadığı yabancı dil öğretme kaygısı ile yabancı dil öğretimine ilişkin öz yeterlik inançları arasındaki ilişkiyi sorguladığı çalışmasında öğretme kaygısının öğretmen adaylarında daha düşük düzeyde olduğu, öz yeterlik algılarının ise yüksek düzeyde olduğu sonuncuna ulaşmıştır. Duman, Göral ve Bilgin'in (2017) İngilizce'yi yabancı dil olarak öğrenen üniversite öğrencileriyle yaptığı nitel araştırmasında, öğrenciler konuşma kaygısının sınıfiçi performanslarını olumsuz etkilediğini belirtmiştir. Aynı çalışmanın bulgularına göre konuşma kaygısının altında yatan sebeplerden bazıları şu şekilde sıralanmıştır: yanındakilerin dalga geçeceğini düşünme, kendilerini başkalarıyla kıyaslama, kalabalık sınıf ortamı ve yanlış yapma endişesi. Doğan'ın (2009) doktora tezinin sonuçlarına göre ise "sosyal anksiyete ve alt boyutları olan sosyal korku, sosyal kaçınma, performans korku, performans kaçınma, sosyal etkileşim korku, sosyal etkileşim kaçınma ile olumsuz değerlendirilme korkusu (...)" arasında pozitif yönde anlamlı bir ilişki vardır. Sosyal anksiyete düzeyleri yüksek olan bireylerin benlik saygısı düzeyleri düşük çıkmıştır. Chen ve Chang (2004), öğrenme güçlükleri ve yabancı dil kaygısı arasındaki ilişkiyi inceledikleri çalışmalarında bu ikisi arasında pozitif bir ilişki olduğunu saptamış, yabancı dil öğrenme güçlüğüne sahip ve yavaş ilerleme gösteren öğrencilerin daha yüksek kaygı yaşadığını ileri sürmüştür.

Türkiye'de alanyazında yapılan çalışmalar incelendiğinde görülmektedir ki çoğu çalışma genel yabancı dil kaygısı düzeyini ölçmeye çalışmıştır. Dilsel kaygının alt boyutlarını ya da nedenlerini inceleyen çalışmalar oldukça azdır. Benzer şekilde özyeterlilik algısı da yabancı dille ilişkili olarak ölçülmüş, genel özyeterlilik çalışılmamıştır. Bu çalışmada farklı olarak yabancı dil öğrencilerinin kaygının alt boyutu olan olumsuz değerlendirilme korkusu ve genel özyeterlilik algıları belirlenmeye çalışılmıştır. Olumsuz değerlendirilme korkusu ve genel özyeterlilik öğrencilerin kişilikleriyle ilgili özelliklerdir ve yabancı dil öğretimine etkisi olduğu düşünülmektedir. Yukarıda da belirtildiği gibi son yıllarda dilsel kaygı üzerine yapılan çalışmalar artmış, kaygının öğrenmeyi ve başarıyı engelleyici boyutu ıspatlanmış ve çeşitli çözüm önerileri sunulmuştur. Tüm bu gelişmelerden sonra yabancı dil öğrencilerinin kaygı durumlarının ve kaygı nedenlerinin ne olduğu ve kaygının yabancı dil sınıflarında hala engelleyi bir unsur olup olmadığı sorusu bu çalışmanın çıkış noktasını oluşturmuştur. $\mathrm{Bu}$ doğrultuda bu çalışmada, kaygının nedenlerinden biri olan olumsuz değerlendirilme korkusu ve kaygıyı dolaylı olarak etkilediği düşünülen genel özyeterlilik algısı arasında bir ilişkinin olup olmadığını belirlemek ve Fransızcayı yabancı dil olarak öğrenen öğrencilerin olumsuz değerlendirilme korkusu düzeyini ve genel özyeterlilik algılarını ölçmek amaçlanmıştır. Bu genel amaç çerçevesinde aşağıdaki sorulara yanıt aranmıştır:

1. Fransızca yabancı dil öğrencilerinin olumsuz değerlendirilme korkusu hangi düzeydedir?

2. Fransızca yabancı dil öğrencilerinin genel özyeterlilik algıları hangi düzeydedir?

Anadolu Üniversitesi Ĕ̆itim Fakültesi Dergisi (AUJEF), 3(4), 239-252 
3. Genel özyeterlilik düzeyi ve olumsuz değerlendirilme korkusu arasında bir ilişki bulunmakta midir?

4. Öğrenim görülen sınıf düzeyi ile olumsuz değerlendirilme korkusu ve genel özyeterlilik düzeyi arasında farklılık bulunmakta mıdır?

\section{YÖNTEM}

Araştırma ilişkisel tarama modelinde desenlenmiştir. İlişkisel tarama modeli "iki ve daha çok sayıdaki değişken arasında birlikte değişimin varlığını ve/veya derecesini belirlemeyi amaçlayan araştırma modelleridir" (Karasar, 2012, s.81). Araştırmada, Fransızca yabancı dil öğrencilerinin olumsuz değerlendirilme korkusu ile genel özyeterlilik algıları arasındaki ilişki, öğrenim görülen sınıf düzeyine göre incelenmiştir. Öğrencilerin olumsuz değerlendirilme korkusu ve genel özyeterlilik düzeyleri belirlenmeye, bu ikisi arasındaki ilişki betimlenmeye ve var olan durum saptanmaya çalışılmıştır.

\section{1. Çalışma Grubu}

Çalışmanın evrenini Anadolu Üniversitesi Fransızca Öğretmenliği Programı’nda 2017-2018 eğitim öğretim yılı bahar döneminde öğrenim görmekte olan 167 öğrenci oluşturmaktadır. Araştırmanın tarama modelinde yapılması, evrenin ulaşılabilir olması ve fazla büyük olmaması nedenleriyle çalışmanın, evrenin tümü üzerinde yapılması planlanmıştır. Bu nedenle örneklem alma yoluna gidilmemiştir. Çalışma evrenini oluşturan 167 öğrenciden 122'si veri toplama aracını yanıtlamış, 45 öğrenci ise veri toplama aracını yanıtlamamıştır. Veri toplama aracını yanıtlayan 122 öğrenciden 25'i 1. sınıfta, 29’u 2. sinıfta, 24'ü 3. sinıfta, 44'ü ise 4. sinıfta öğrenim görmektedir.

\subsection{Veri Toplama Araçları}

Çalışmada öğrencilerin olumsuz değerlendirilme korku düzeylerini belirlemek için Olumsuz Değerlendirilme Korkusu Ölçeği Kısa Formu kullanılmış, özyeterliliklerini belirlemek için ise Genel Özyeterlilik Ölçeği kullanılmıştır. Her iki ölçek kullanılmadan önce ölçeğin uyarlamasını yapan yazarlardan birisiyle bağlantıya geçilerek izin alınmıştır.

\subsubsection{Olumsuz Değerlendirilme Korkusu Ölçeği Kısa Formu (ODKO)}

Olumsuz Değerlendirilme Korkusu Ölçeği Kısa Formu Leary (1983) tarafindan geliştirilen, bireylerin başkalarının olumsuz değerlendirmesi ve olumsuz tavırlarına karşı tutumu ölçen bir ölçektir ve Çetin, Doğan ve Sapmaz (2010) tarafindan Türkçeye uyarlanmıştır. Leary (1983) tarafindan hazırlanan ölçek 12 maddeden oluşmaktadır ve maddeler (1) Hiç uygun değil ve (5) Tamamen Uygun biçiminde 5'li Likert tipi bir derecelendirilmeye sahiptir. 8 madde olumsuz değerlendirilmeye ilişkin korku ve endişe ifadelerinden oluşurken, kalan 4 madde korku ve endişelerin olmadığ 1 şeklinde tersten puanlanmaktadır. Çetin ve arkadaşları (2010) tarafından Türkçeye uyarlanan ölçeğin bir maddesi "madde toplam korelasyonu değerinin (-.03) ve faktör analizi sonucu faktör yükünün kabul edilebilir düzeyde olmadı̆̆ı" gözlemlendiği için çıkarılmış, toplam 11 maddelik bir ölçek haline getirilmiştir. Ölçeğin iki faktörlü ve tek faktörlü yapısı hem açımlayıcı hem doğrulayı faktör analizi yapılarak test edilmiş, sonuç olarak ölçeğin tek faktörlü olarak kullanılmasının daha uygun olacağı görüşü ortaya 
konmuştur. Ölçeğin güvenirliği iç tutarlılık (Cronbach Alpha), test yarılama (.83) ve test-tekrar test (.82) yöntemleriyle hesaplanmış, iç tutarlılık katsayısı. 84 olarak bulunmuştur.

$\mathrm{Bu}$ çalışmada da Çetin ve arkadaşları tarafindan uyarlanan form kullanılmış, uyarlanan formun faktör yapısının bu çalışmanın örnekleminde doğrulanıp doğrulanamayacağını test etmek üzere doğrulayıcı faktör analizi yapılmıştır. Doğrulayıcı faktör analizi (DFA) elde edilen verinin daha önce farklı çalışmalarda belirlenmiş olan faktör yapısına uyup uymadığını test etmek için yapılmaktadır (Seçer, 2013:134). Ulaşılan evrenin sınırlı sayıda olması nedeniyle doğrulayıcı faktör analizi aynı veri üzerinden yapılmıştır. MPlus programı yardımıyla ölçeğin tek faktörlü ve iki faktörlü yapısı test edilmiş, iki faktörlü yapının uyum indeksi değerlerinin (RMSEA=0.096, CFI=0.94) daha iyi olduğu görülmüş, ölçek iki faktörlü olarak kullanılmıştır. Güvenilirlik açısından Cronbach Alfa katsayısı hesaplanmış, tüm maddeler için iç tutarlılık katsayısı .62 olarak hesaplanmıştır. Bu bağlamda araştırmada kullanılan ölçeğin doğrulayıcı faktör analizi sonucunda geçerli ve Cronbach Alfa katsayılarına dayalı olarak güvenilir bir ölçek olduğu söylenebilir.

\subsubsection{Genel Özyeterlilik Ölçeği}

Genel Özyeterlilik Ölçeği'nin özgün formu Sherer, Maddux ve Mercandante (1982) tarafından geliştirilmiş, Yıldırım ve İlhan (2010) tarafından Türkçeye uyarlama çalışması yapılmıştır. Ölçeğin özgün formu Genel Özyeterlilik ve Sosyal Özyeterlilik olmak üzere iki faktörlü bir yapı ortaya koymuştur. İlk hali 14 dereceli olan ölçek daha sonra beş dereceli Likert tipi bir ölçeğe dönüştürülmüş̧ür. Uyarlama çalışmasında ölçeğin 5 dereceli Likert formatı kullanılmıştır. Ölçeğin faktör yapısı açımlayıcı faktör analizi sonucunda üç faktörlü olarak belirlenmiştir. "Birinci faktörün özdeğeri 4.150, açıkladığı varyans \%20,2; ikinci faktörün özdeğeri 1.786 , açıkladığı varyans $\% 11,9$ ve üçüncü faktörün özdeğeri 1.114, açıkladığ1 varyans \%9,5 olarak” bulunmuştur (ibid.). Bu faktörlerin adları sırasıyla: Başlama, Yılmama ve Sürdürme Çabası-Israr olarak belirlenmiştir ve üç faktörlü yapı toplam varyansın \%41,47'sini açıklamaktadır. Ölçeğin güvenirliği için iç tutarlılık (Cronback Alfa $=0,80)$, iki yarım güvenirliği $(0,77)$, test-tekrar-test güvenirliği (Perason r=0,69) hesaplanmıştır.

Bu çalışmada ise Yıldırım ve İlhan (2010) tarafından uyarlanan form kullanılmış, uyarlanan formun faktör yapısının bu çalışmanın örnekleminde doğrulanıp doğrulanamayacağını test etmek üzere doğrulayıcı faktör analizi yapılmıştır. Ulaşılan evrenin sınırlı sayıda olması nedeniyle doğrulayıcı faktör analizi aynı veri üzerinden yapılmıştır. Mplus programı ile yapılan doğrulayıcı faktör analizi sonucunda aynı şekilde üç faktörlü yapı doğrulanmış, uyum indeksi değerlerinin (RMSEA=0.097, $\mathrm{CFI}=0.86$ ) uygun olduğu saptanmıştır. Güvenirlik için hesaplanan iç tutarlılık katsayısı (Cronbach Alfa $=0,91$ ) orijinal ölçekle benzer şekilde bulunmuştur.

\subsection{Verilerin Analizi}

Araştırma verilerinin çözümlenmesinde Spss 24 programı kullanılmıştır. Öncelikle her bir faktör için toplam faktör puanları hesaplanmış, tek örneklem t-testi yapılarak her bir faktör için ortalama puanlar elde edilmiştir. İki ölçeğin arasındaki ilişki düzeyini belirlemek için Pearson korelasyon analizi yapılmış, sınıflar arasındaki farkı belirlemek için ise tek yönlü ANOVA yapılmıştır. 


\section{BULGULAR}

Araştırmanın birinci ve ikinci alt amacı öğrencilerin olumsuz değerlendirilme korkusu düzeyini ve özyeterliliklerini belirlemektir. Bu amaca yönelik olarak her bir faktöre uygulanan tek örneklem ttesti sonuçları Tablo 1'de gösterilmiştir.

Tablo 1. Her bir alt faktör için tek örneklem t-testi sonuçları

\begin{tabular}{lccccccc}
\hline & $\mathbf{N}$ & $\mathbf{X}$ & $\begin{array}{l}\text { Sig.(2 } \\
\text { tailed) }\end{array}$ & $\begin{array}{l}\text { Ortalamadan } \\
\text { farkı }\end{array}$ & t & sd & S \\
\hline Başlama & 122 & 34,56 &, 000 & 7,56243 & 11,128 & 121 & 7,50 \\
Y1lmama & 122 & 15,96 &, 008 &, 96648 & 2,685 & 121 & 3,97 \\
Sürdürme çabas1 & 122 & 9,44 &, 041 &, 44893 & 2,069 & 121 & 2,39 \\
ODK F1 & 122 & 18,30 &, 000 & $-5,69672$ & $-8,931$ & 121 & 7,04 \\
ODK F2 & 122 & 9,82 &, 002 &, 82787 & 3,201 & 121 & 2,85 \\
\hline \hline
\end{tabular}

Tablo 1'deki veriler incelendiğinde özyeterlilik ölçeğinin "başlama" alt faktörü puanları incelenen 122 katılımcının puan ortalamalarının beklenen ortalama başlama alt faktör puanı olan 27 'den farklı olup olmadığını belirlemek için yapılan tek örneklem t testi sonucunda katılımcıların başlama alt faktörü ortalamalarının beklenen değerden anlamlı derecede yüksek olduğu görülmüştür $\left(\mathrm{t}_{(121)}=, \mathrm{p}<0.01\right)$. Test sonucu hesaplanan etki büyüklüğü $\mathrm{d}=1$ farkın büyük olduğunu göstermektedir. Özyeterlilik ölçeğinin ikinci alt faktörü olan "yılmama" alt faktörü puanları incelenen 122 katılımcının puan ortalamalarının beklenen ortalama yılmama alt faktör puanı olan $15^{\prime}$ 'den farklı olup olmadığını belirlemek için yapılan tek örneklem $\mathrm{t}$ testi sonucunda katılımcıların bu faktöre ilişkin ortalamalarının beklenen değerden anlamlı derecede ve yüksek olduğu görülmüştür $\left(\mathrm{t}_{(121)}=, \mathrm{p}<0.01\right)$. Test sonucu hesaplanan etki büyüklüğü $d=0,24$ farkın küçük olduğunu göstermektedir. Özyeterlilik ölçeğinin "sürdürme çabası" alt faktörü puanları incelenen 122 katılımcının puan ortalamalarının beklenen ortalama sürdürme çabası alt faktör puanı olan 9'dan farklı olup olmadığını belirlemek için yapılan tek örneklem t testi sonucunda katılımcıların sürdürme çabası alt faktörü ortalamalarının beklenen değerden anlamlı derecede yüksek olduğu görülmüştür $\left(\mathrm{t}_{(121)}=, \mathrm{p}<0.01\right)$. Test sonucu hesaplanan etki büyüklüğü $\mathrm{d}=0,18$ farkın küçük olduğunu göstermektedir. Olumsuz değerlendirilme korkusu ölçeğinin birinci faktörü olan ve korkunun olduğunu bildiren ilk faktör puanları incelenen 122 katılımcının puan ortalamalarının beklenen ortalama olumsuz değerlendirilme korkusu alt faktör puanı olan 24 'ten anlamlı derecede düşük olduğu görülmüştür. $\left(\mathrm{t}_{(121)}=, \mathrm{p}<0.01\right)$. Test sonucu hesaplanan etki büyüklüğü $\mathrm{d}=0,80$ farkın büyük olduğunu göstermektedir. Olumsuz değerlendirilme korkusu ölçeğinin ikinci faktör puanları incelenen 122 katılımcının puan ortalamalarının beklenen alt faktör puanı olan 9'dan anlamlı derecede yüksek olduğu görülmüştür. Test sonucu hesaplanan etki büyüklüğü $d=0,28$ farkın küçük olduğunu göstermektedir.

Araştırmanın üçüncü alt amacı olan "Öğrenim görülen sınıf ile olumsuz değerlendirilme korkusu ve genel özyeterlilik düzeyi arasında farklılık bulunmakta mıdır?” sorusuna Pearson korelasyon analizi ile cevap aranmıştır. Olumsuz değerlendirilme korkusu ve özyeterlik algısı değişkenleri arasındaki ilişkiyi gösteren korelasyon katsayıları Tablo 2'de gösterilmiştir. 
Tablo 2. Olumsuz değerlendirilme korkusu ve özyeterlilik inancı arasındaki korelasyon sonuçları

\begin{tabular}{lcc}
\hline Değişkenler & Odko 1. Faktör & Odko 2. faktör \\
\hline Başlama & $-0,576^{*}$ & $0,357^{*}$ \\
Yılmama & $-0,527^{*}$ & $0,381^{*}$ \\
Sürdürme çabası & $-0,201^{*}$ & $0,164^{* *}$
\end{tabular}

$* \mathbf{p}<0,01 * * \mathbf{p}>0,05$

Tablo 2'teki veriler incelendiğinde, genel özyeterliliğin tüm alt boyutları ile olumsuz değerlendirilme korkusu arasında .01 anlamlılık düzeyinde ilişkiler olduğu görülmüştür. Sadece sürdürme çabası ile olumsuz değerlendirilme korku ve endişelerin olmadığına dair maddelerden oluşan ODKO'nun ikinci faktörüyle anlamlı düzeyde bir ilişki bulunamamıştır. Özyeterliliğin alt faktörü olan başlama ile olumsuz değerlendirilme korkusu arasında negatif yönde, orta düzeyde ve anlamlı; yılmama ile olumsuz değerlendirilme korkusunun birinci faktörü arasında negatif yönde, orta düzeyde ve anlamlı; sürdürme çabası ile olumsuz değerlendirilmenin birinci faktörü ile yine negatif yönde, düşük düzeyde ve anlamlı ilişkiler olduğu belirlenmiştir. Tersten puanlanan ve olumsuz değerlendirilme korkusu ve endişesinin olmadığını bildiren maddelerden oluşan ODKO'nun ikinci faktörü ile özyeterliliğin tüm alt boyutları arasında pozitif yönde ve düşük düzeyde ilişki olduğu belirlenmiştir. Başka bir ifadeyle katılımcıların başlama, yılmama ve sürdürme davranışı arttı̆̆ında olumsuz değerlendirilme korkusu düşmekte ve karş1lıklı olarak olumsuz değerlendirilme korkusu düştüğünde başlama, yılmama ve sürdürme davranışlarında yükselme görülmektedir.

Araştırmanın son alt amacı olan öğrenim görülen sınıf $(1,2,3,4)$ ile olumsuz değerlendirilme korkusu ve genel özyeterlilik düzeyi arasında farklılık bulunup bulunmadığını test etmek için tek yönlü ANOVA yapılmıştır. Her bir faktör ile öğrenim görülen sınıf düzeyi karşılaştırılmıştır ve sınıf düzeyinin anlamlı bir fark oluşturmadığı görülmüştür. Elde edilen sonuçlar Tablo 3 'te verilmiştir.

Tablo 3. Ö̆grenim görülen sınıf ile olumsuz değerlendirilme korkusu alt faktörleri ve özyeterlilik alt faktörleri arasındaki farkı gösteren tek yönlü ANOVA sonuçları

\begin{tabular}{|c|c|c|c|c|c|c|}
\hline & & Karelerin toplamı & $\mathrm{sd}$ & kareler ortalaması & $\mathrm{F}$ & $\mathrm{p}$ \\
\hline \multirow[t]{3}{*}{ ODKO 1. faktör } & Gruplar arası & 91,553 & 3 & 30,518 &, 598 &, 618 \\
\hline & Gruplar içi & 6022,545 & 118 & 51,039 & & \\
\hline & Toplam & 6114,098 & 121 & & & \\
\hline \multirow[t]{3}{*}{ ODKO 2. Faktör } & Gruplar aras1 & 15,990 & 3 & 5,330 & 1,372 &, 255 \\
\hline & Gruplar içi & 458,305 & 118 & 3,884 & & \\
\hline & Toplam & 474,295 & 121 & & & \\
\hline \multirow[t]{3}{*}{ Sürdürme Çabas1 } & Gruplar aras1 & 5,293 & 3 & 1,764 & 278 & 841 \\
\hline & Gruplar içi & 749,830 & 118 & 6,354 & & \\
\hline & Toplam & 755,123 & 121 & & & \\
\hline \multirow[t]{3}{*}{ Y1lmama } & Gruplar aras1 & 9,262 & 3 & 3,087 & ,372 & ,773 \\
\hline & Gruplar içi & 978,123 & 118 & 8,289 & & \\
\hline & Toplam & 987,385 & 121 & & & \\
\hline \multirow[t]{3}{*}{ Başlama } & Gruplar arası & 71,369 & 3 & 23,790 & ,473 & ,702 \\
\hline & Gruplar içi & 5934,410 & 118 & 50,292 & & \\
\hline & Toplam & 6005,779 & 121 & & & \\
\hline
\end{tabular}


Tablo 3'teki veriler incelendiğinde öğrenim görülen sınıf ile olumsuz değerlendirilme korkusunun tüm faktörleri ve özyeterliliğin tüm faktörleri arasında anlamlı bir fark yoktur. Öğrenim görülen sınıfla karşılaştırıldığında olumsuz değerlendirilme korkusunu birinci faktörü $(F[3,118]=0,598$, $\mathrm{p}>, 05)$, ikinci faktörü $(\mathrm{F}[3,118]=1,372, \mathrm{p}>, 05)$, özyeterliliğin sürdürme çabas1 alt faktörü $(F[3,118]=0,278, \quad p>, 05)$, y1lmama faktörü $(F[3,118]=0,372, \quad p>, 05)$ ve başlama alt faktörü $(\mathrm{F}[3,118]=0,473, \mathrm{p}>, 05)$ puanları üzerinde anlamlı farklılıklara neden olmadığı görülmüştür.

\section{TARTIŞMA ve SONUÇ}

Olumsuz değerlendirilme korkusu yabancı dil kaygısının güçlü nedenlerinden biridir ve dil öğrenmedeki başarıyı etkilediği çeşitli çalışmalarla (Aydın, 2008; Dalkılıç, 2001; Koralp, 2005) ortaya konmuştur. Genel özyeterlilik inancı ise öğrenmeyi olumlu yönde etkileyen bir faktör olarak görülmektedir. Öğrencinin özyeterliliği ne kadar fazlaysa derse o kadar ilgilidir ve ne kadar çok ilgili olursa o kadar çok öğrenir ve dolayısıyla daha iyi performans gösterir (Çubukçu, 2008). Fransızcayı yabancı dil olarak öğrenen öğrencilerin olumsuz değerlendirilme korkusu ve genel özyeterlilik düzeylerini ölçmeyi amaçlayan bu çalışma sonucunda Fransızca yabancı dil öğrencilerinin özyeterlilik algılarının yüksek olduğu ve olumsuz değerlendirilme korkularının ise düşük seviyede olduğu belirlenmiştir. Özyeterlilik ölçeğine ait olan bir işe başlama ile ilgili faktör puanları genel ortalamadan yüksek, yılmama ve işi sürdürme çabası ise ortalamanın biraz üstünde çıkmıştır. Ortalaması en yüksek düzeyde çıkan faktör başlama faktörüdür. Bu bağlamda öğrencilerin bir işe başlarken kendilerini oldukça yeterli gördüklerini, yılmama ve sürdürme (1srar) aşamasında ise orta düzeyde yeterli gördüklerini söyleyebiliriz. Olumsuz değerlendirilme korkusuna (ODK) ilişkin ise olumsuz değerlendirilme korkusu olduğunu bildiren maddelerden oluşan faktörün puanları ortalamanın altında (düşük düzeyde), olumsuz değerlendirilme korkusunun olmadığını belirten faktörün puanları ise ortalamanın biraz üzerindedir. Yani Fransızca öğretmen adayı olan öğrencilerin olumsuz değerlenirilme korkuları düşük düzeydedir. İlk faktörün sonuçları, tersten puanlanan ikinci faktörün sonuçlarıyla örtüşmektedir. Merç'in (2015) İngilizce öğretmen adaylarıyla yaptı̆̆ı benzer çalışmanın sonuçları da öğretmen adaylarının özyeterlilik algılarının yüksek düzeyde olduğunu, yabancı dil kaygılarının ise düşük düzeyde olduğunu göstermektedir. Burada yabancı dil kaygısının katılımcıların öğretmen adayı olmalarından dolayı düşük olup olmadığı sorusu akla gelmektedir.

Olumsuz değerlendirilme korkusu ile genel özyeterlilik arasında bir ilişki bulunup bulunmadığına dair yapılan analizlerin sonucunda bu ikisi arasında negatif düzeyde ve anlamlı bir ilişki bulunduğu sonucuna ulaşılmıştır. Katılımcıların bir işe başlama, yılmama ve sürdürme konusundaki özyeterlilikleri arttıkça olumsuz değerlendirilme korkuları düşmektedir. Başlama ve ODK arasındaki ilişki negatif yönde ve orta düzeyde, yılmama ve ODK arasındaki ilişki negatif yönde ve orta düzeyde, sürdürme çabası ve ODK arasındaki ilişki ise yine negatif yönde ve düşük düzeydedir. ODKO'nun tersten puanlanan ikinci faktörü ile özyeterliliğin tüm faktörleri arasında ise pozitif yönde ve düşük düzeyde ilişki çıkmıştır. Bu sonuçlar birbirlerini destekler niteliktedir. Öğrencilerin bir işe başlama ve onu sürdürme konusundaki özyeterliliği artıkça olumsuz değerlendirilme korku ve endişesi azalmakta ya da tam tersi olumsuz değerlendirilme korkusu düştükçe özyeterlilik inancı artmaktadır. Olumsuz değerlendirilme korkusunun genellikle kişinin bir işe başlarken ya da performans göstermesi gereken durumlarda yaşadığı bir durum olduğu göz önüne alındığında işe başlama konusunda özyeterliliğin artmasının korkuyu ve endişeyi aşağı çekmesi beklenen bir durumdur. Çubukçu da (2008), yabancı dil kaygısı ile özyeterlilik arasındaki ilişkiyi incelediği çalışmasında bu ikisi arasında anlamlı bir ilişkinin 
olmadığını fakat öz yeterliliği düşük olanların öz yeterliliği yüksek olan öğrencilere göre daha yüksek kaygı düzeyi olduğunu ileri sürmüştür.

Öğrencilerin öğrenim gördükleri sınıfa göre ODK ve özyeterlilikleri arasında anlamlı bir farklılık olup olmadığına dair yapılan analiz sonuçlarına göre öğrenim görülen sınıf herhangi bir fark oluşturmamaktadır. Birinci sınıftaki öğrencilerin de son sınıftaki öğrencilerin de olumsuz değerlendirilme korkusu ve özyeterlilik inançları konusunda bir farklılık yoktur. Oysa Sparks ve Ganschow (2007) öğrencilerin yabancı dil kaygılarının dil becerileri geliştikçe azalacağını belirtmektedir. Bu örneklem için böyle bir durum ortaya çıkmamıştır.

$\mathrm{Bu}$ çalışma yabancı dil öğretmen adaylarıyla yapılmasına karşın, kullanılan ölçekler genel özyeterlilik ve genel olumsuz değerlendirilme kaygısı ölçekleridir. Alanyazında daha önce yapılan çalışmalarda yabancı dil öğrencilerinin yabancı dil kaygılarının yüksek olduğu sonucuna ulaşılmasına rağmen bu çalışmada dil kaygısının sebeplerinden biri olarak kabul edilen olumsuz değerlendirilme korkularının bu örneklem için yüksek olmadığı sonucuna ulaşılmıştır. Bu öğrenciler açısından istenen ve olumlu bir sonuçtur. Zira olumsuz değerlendirilme korkusu dilsel kaygının önemli sepeblerinden biridir. Ayrıca bu öğrencilerin genel özyeterlilik algılarının yüksek olmasının da onların düşük kaygı ve korku yaşamasını etkileyen bir durum olduğu söylenebilir. Dilsel kaygının sadece bir boyutunu ölçen bu çalışma farklı ölçekler kullanılarak yinelenebileceği gibi genel dil kaygısını ölçen bir ölçek kullanılarak geliştirilebilir ve böylece öğrencilerin dilsel kaygı yaşayıp yaşamadığı, yaşıyorlarsa bunun olumsuz değerlendirilme korkusu haricinde hangi nedenlerden kaynaklanıyor olduğu tespit edilebilir. Bunun için ayrıca nitel verilerden destek alınabilir. Dilsel korkunun ve kaygının düşük olduğu sınıflar oluşturmak için öğrencilerin öz yeterlilik inançlarını destekleyecek ve geliştirecek çeşitli etkinlikler yapılmalıdır. Zira öz yeterlilik inancı dilsel kayıg ve olumsuz değerlendirmeyi azaltan bir etkiye sahiptir. Öğretmenlerin bu konuda hassas davranması, öğrencilerinin öz yeterlilik algısını zedeleyecek davranışlardan kaçınmaları oldukça önemlidir. Son olarak, araştırmanın çıkış noktasını oluşturan, dilsel kaygı üzerine yapılan bunca araştırmadan sonra yabancı dil öğrencilerinin kaygı ve korku düzeylerinin hala yüksek olup olmadığına dair duyulan merak, öğrencilerin olumsuz değerlendirilme kaygılarının düşük çıkmasıyla birlikte biraz olsun giderilmiştir. Zira bu durum alanda yapılan çalışmaların etkili ve faydalı olduğu, öğrencilerin kaygı düzeyini azaltmakta yardımcı olduğu çıkarımını mümkün kılmaktadır. Ayrıca yabancı dil öğrenen öğrencilerinin genel özyeterlilik algılarının yüksk olmasının yabancı bir dil öğrenmeyle ilişki olduğu düşünülebilir. Zira yeni bir dil ve kültür öğrenmek bireyi zenginleştirirken aynı zamanda özgüven, özsaygı ve özyeterlilik gibi kişilik özeliklerine de olumlu katkı yapabilmektedir. Zira bir topluluk içinde ikinci bir dil öğrenmek ve bu dili kullanmak tüm bu kişilik özelliklerini kullanmayı ve geliştirmeyi zorunlu kılmaktadır.

\section{Teşekkür}

Bu çalışmanın ortaya çıkmasına vesile olan ve yöntem kısmında, özellikle veri toplama ve analizi konularında cömert yardımlarını esirgemeyen değerli hocam Doç. Dr. Murat AKYILDIZ'a sonsuz teşekkürlerimi sunarım. 


\section{KAYNAKLAR}

Aslım Yetiş, V. (2012). La production orale en langue etrangère: vaincre l'anxiété. Uludağ Üniversitesi Eğitim Fakültesi Dergisi, 25(1), 145-166.

Arnold, J. (2006). Comment les facteurs affectifs influencent-ils l'apprentissage d'une langue étrangère ? Ela. Études de linguistique appliquée, 4(144), 407-425. 25 Haziran 2018 tarihinde https://www.cairn.info/revue-ela-2006-4-page-407.htm adresinden erişim sağlanmıştır.

Aydın, S. (2008). An Investigation on the language anxiety and fear of negative evaluation among Turkish EFL learners. Asian EFL Journal, 421-444.

Bandura, A. (1997). Self-Efficacy: The Exercise of Control. New York: W.H. Freeman and Company.

Chen, T.Y. \& Chang, G.B.Y. (2004). The relationship between roreign language anxiety and learning difficulties. Foreign Language Annals, 37(2), 279-289.

Conseil de l'Europe (2001). Cadre Européen Commun de Référence pour les Langues : Apprendre, Enseigner, Evaluer [CECR], Paris: Didier.

Çapan Tekin, S. (2015). Réduire/Vaincre l'Anxiété Langagière en Production Orale avec les Jeux de Rôles : Une Expérience avec des Etudiants de FLE de L'Université Anadolu. Yayımlanmamış yüksek lisans tezi. Anadolu Üniversitesi, Eskişehir.

Çetin,B., Doğan, T.\& Sapmaz, F. (2010). Olumsuz değerlendirilme korkusu ölçeği kısa formu'nun Türkçe uyarlaması: geçerlik ve güvenirlik çalışması. Eğitim ve Bilim, 35(156), 205-216.

Çubukçu, F. (2008). A study on the correlation between self efficacy and foreign language learnıng anxıety. Eğitimde Kuram ve Uygulama, 4(1), 148-158.

Dalkilic, N. (2001). An investigation into the role of anxiety in second language learning. Yayımlanmamış doktora tezi. Çukurova Üniversitesi, Adana.

Doğan, T. (2009). Bilişsel ve kendini değerlendirme sureclerinin sosyal anksiyete acisindan incelenmesi. Yayımlanmamış doktora tezi. Sakarya Üniversitesi Sosyal Bilimler Enstitüsü, Sakarya.

Duman, B., Göral, N.G. \& Bilgin, H. (2017). Üniversite öğrencilerinin sınıf ortamında yabancı dil konuşma kaygısı üzerine nitel bir çalışma. Adnan Menderes Üniversitesi Eğitim Fakültesi Eğitim Bilimleri Dergisi, $8(2), 13-27$.

Güngör, F., \& Yayl1, D. (2012). Self-efficacy and anxiety perceptions of pre-service EFL teachers. In A. Akbarov \& V. Cook (Eds.), Approaches and Methods in Second and Foreign Language Teaching (227-236). Sarajevo: IBU Publications.

Hamamcı, Z. \& Hamamcı, E. (2015). Yabancı dil öğreniminde kaygı üzerine bir alanyazın taraması. Eğitim ve Öğretim Araştırmaları Dergisi, 4(4), 374-383.

Huang, J. (2012). Overcoming Foreign language Classroom Anxiety. New York: Nova. https://ebookcentral.proquest.com/lib/anadolu/reader.action?docID=3019849\&query

Karasar, N. (2012). Bilimsel Araştırma Yöntemi. Ankara: Nobel Yayıncılık.

Koralp, S. (2005). A retrospective analysis of the English languagelearning anxiety experienced by prospective teachers of English. Yayımlanmamış yüksek lisans tezi. Turkey.

Leary, M.R. (1983). A Brief version of the fear of negative evaluation scale. Personality and Social Psychology Bulletin, $\quad 9(3), \quad 371-375 . \quad 11 \quad$ Nisan $2018 \quad$ tarihinde http://journals.sagepub.com/doi/abs/10.1177/0146167283093007 adresinden erişim sağlanmıştır.

MacIntyre, P.D. (1995). How does anxiety affect second language learning? A reply to Sparks and Ganschow. The Modern Language Journal, 79(1), 90-99. 20 Mayıs 2018 tarihinde http://www.jstor.org/stable/329395 adresinden erişim sağlanmıştır.

Merç, A. (2015). Foreign language teaching anxiety and self-efficacy beliefs of Turkish pre-service EFL teachers. The International Journal of Research in Teacher Education, 6(3), 40-58.

Mills, N. (2014). Self-efficacy and second language acquisition. Sarah Mercer And Marrions Williams (Ed.), in Multiple Perspectives on the Self in SLA (pp. 6-19). Multilingual Matters. 
Mills, N., Pajares, F. \& Herron, C. (2007). Self-efficacy of College Intermediate FrenchStudents: Relation to Achievementand Motivation. Language Learning, 57(3), 417-442. 1 Temmuz 2019 tarihinde https://onlinelibrary.wiley.com/doi/epdf/10.1111/j.1467-9922.2007.00421.x adresinden erişim sağlanmıştır.

Öner, G. \& Gedikoğlu, T. (2007). Ortaöğrenim öğrencilerinin İngilizce öğrenimlerini etkileyen yabancı dil kaygısı. Gaziantep Üniversitesi Sosyal Bilimler Dergisi, 6(2), 67-78.

Rahimi, A. \& Abedini, A. (2009). The interface between efl learners' self-efficacy concerning listening comprehension and listening proficiency. Novitas-ROYAL, 3(1), 14-28. 1 Temmuz 2019 tarihinde http://pegem.net/dosyalar/dokuman/124476-20110815121542-2.pdf adresinden erişim sağlanmıştır.

Seçer, İ. (2013). SPSS ve LISREL ile Pratik Veri Analizi. Ankara: Anı Yayıncılık.

Sherer, M., Maddux J.E., Mercandante, B. ve ark. (1982) The Self-Efficacy Scale: construction and validation. Psychol Rep, 51(2): 663-671. $\quad 15 \quad$ Nisan 2018 tarihinde http://journals.sagepub.com/doi/abs/10.2466/pr0.1982.51.2.663 adresinden erişim sağlanmıştır.

Yıldırım, F. \& İlhan, İ. Ö. (2010). Genel özyeterlilik ölçeği Türkçe formunun geçerlilik ve güvenirlik çalışması. Türk Psikiyatri Dergisi, 21(4), 301-8.

Yoğurtçu, K. \& Yoğurtçu, G. (2013). Yabancı dil olarak Türkçenin öğretiminde kaygının akademik başarıya etkisi. Adlyaman Üniversitesi Sosyal Bilimler Enstitüsü Dergisi, 6(11), 1115-1158.

Young, D.J. (1991). Creating a low-anxiety classroom environment: what does language anxiety research suggest? The Modern Language Journal, 75(4), 426-439. 20 Mayı 2018 tarihinde http://www.jstor.org/stable/329492 adresinden erişim sağlanmıştır. 


\section{EXTENDED ABSTRACT}

\section{Introduction}

In foreign language teaching, affective factors are as important as cognitive factors. The affective factors are attitudes of learners, motivation, values, beliefs and personality traits and so forth. Among such factors, the most common and difficult factor is anxiety. Anxiety is the feeling of subjective tension and irritability, and is associated with the stimulation of the autonomic nervous system. Foreign language anxiety is defined as 'anxiety and negative emotional reaction when a second language is learned or used' (Young, 1999; as cited in Hamamci \& Hamamci, 2015, p. 375). Several researchers have shown that anxiety affects learning and success negatively. According to Hortwitz et al. (1986) (as cited in Capan, 2015), there are three sources of language anxiety: communication anxiety, test anxiety and fear of negative evaluation. Fear of negative evaluation is the fear and social phobia that can be encountered not only in class environment but also in social environment. In foreign language classes, students are constantly monitored and evaluated by their teacher and other students. An individual who experiences negative evaluation anxiety may continuously think that others will make negative comments about him/her, which can lead to failure to communicate. When the studies on the field of language teaching are examined, most of them have measured the level of general foreign language anxiety. However, there are few studies that have investigated the reasons and/or the sub-dimensions of language anxiety.

In this study, the level of fear of negative evaluation which is one of the reasons of language anxiety and self-efficacy beliefs of French language teaching undergraduate students were investigated. Specifically, the present study was carried out to examine the relationship between these two variables.

\section{Method}

The sample of the current study consisted of 122 students who studied in the department of French Language Teaching during the Spring Semester of 2017-2018 Academic Year. The data were collected by "The Brief Fear of Negative Evaluation Scale" and "The General Self-Efficacy Scale". The data were analyzed using one sample t-test, Pearson correlation analysis and one-way ANOVA. In order to determine whether the scales utilized was appropriate to the research context, confirmatory factor analysis was conducted. Results of the analysis showed that 'Fear of Negative Evaluation' scale had two-factor structure since the factors had better values of fit index (RMSEA=0.096; CFI=0.94) when computed as two-factor format. Likewise, 'General Self-efficacy Beliefs' scale was found to have three-factor structure as the values of fit index were found better when computed in terms of three-factorial format (RMSEA $=0.097$; $\mathrm{CFI}=0.86$ ). Those values indicated a good fit between the model and the observed data for both for scales; therefore, two scales were proved to be valid in the present study.

\section{Result and Discussion}

According to the results of the study, it was found that the level of general self-efficacy of French language teaching students was high and the level of their fear of negative evaluation was low. In addition, it was revealed that there is a positive, moderate and statistically significant relationship between the fear of negative evaluation and the general self-efficacy beliefs. When self-efficacy levels of the participants about their beginning to work, not giving up and maintaining it increase, their fear of negative evaluation levels decreases or vice versa. The grade in which the sample studied did not differ in terms of fear of negative evaluation and general self-efficacy variables. 
Although previous studies in literature have found that foreign language students have had a high level of foreign language concerns, this study has reached the conclusion that the level of fear of negative evaluation, considered as one of the reasons of language anxiety, is not high for this sample. This is a desirable and positive result for the students.

Keywords: Anxiety, fear of negative evaluation, self-efficacy, foreign language teaching 